\title{
Microbial Studies of Prepared Curries Stored in Tin Free Steel Cans Pushparajan $\mathbf{N}^{*}$, Varadharajan D and Soundarapandian $\mathbf{P}$
}

Faculty of Marine Sciences, Centre of Advanced Study in Marine Biology, Annamalai University, Parangipettai-608502, Tamil Nadu, India

\begin{abstract}
Apart from the nutrient analysis microbial study is very much essential to know the microbial contamination after storage. So in the present study it is aimed to investigate the microbial contamination in the prepared fish and shellfish curries stored in tin free steel cans. The prepared curries of fish, shrimp, crab and mussel were stored in TFS cans at room temperature $\left(30 \pm 2^{\circ} \mathrm{C}\right)$ for a period of 18 months. During storage the cans were periodically checked in the intervals of $3^{\text {rd }}, 6^{\text {th }}$ and $12^{\text {th }}$ months especially the visual signs of internal and external rusting like appearance of can walls, adhesion of product to the can walls and internal rusting. About eight cans were selected

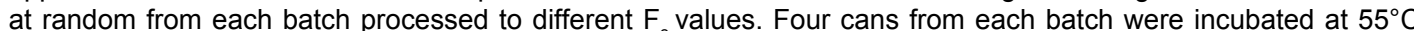
for 4 days and another four were incubated at $37^{\circ} \mathrm{C}$ for 14 days. The incubated cans were opened under aseptic conditions and the samples were transferred to sterile thioglycollate broth tubes. Then a layer of sterile liquid paraffin was applied in each tube so as to create anaerobic condition. The tubes were then incubated at $37^{\circ} \mathrm{C}$ for $48 \mathrm{hrs}$ and observed for any development of turbidity, which indicates survival of microorganisms. Tubes not showing any turbidity were incubated for further $48 \mathrm{hrs}$ at $37^{\circ} \mathrm{C}$ to ascertain the sterility. Besides the above microbiological quality was assessed from the fish, shrimp, crab and mussel curries by standard plate count, total coliform count and total fungal count, according to APHA. The microorganisms are totally absent in the present study for short and longer time storage (3 to 18 months) of fish and shellfish curries stored in TFS cans. Apart from that there is no internal and external rusting, texture during the storage period. So it is conform that TFS cans are suitable to store the fish and shellfish products as evidence by no microbial growth and also not affecting the nutritional quality of the stored food.
\end{abstract}

Keywords: Fish and shellfish; Curries; Stored; Tin free steel cans; Microbial growth

\section{Introduction}

Fish is today universally recognized as the ultimate answers to the problems of protein-caloric malnutrition of the world to the poor undernourished in the third world. It is the best quality protein feed available at affordable price. Fish is an important part of a healthy diet. It is an excellent source of quality proteins, essential fatty acids (omega-3) and many other nutrients important for optimal health and prevention of diseases [1]. The International Food Policy Research Institute [IFPRI]/World Fish Centre study on global fish demand [2] predicts the total demand for fish products will increase from 91.3 million tons in 1997 to 127.8 million tons in 2020 , equating to an annual growth of $1.47 \%$ and a per capita annual consumption increase from $15.7 \mathrm{~kg}$ to $17.1 \mathrm{~kg}$ in 2020 [3]. With the ever growing world population and the need to store and transport the food from one place to another where it is needed, food preservation becomes necessary in order to increase its shelf life and maintain its nutritional value, texture and flavor. Therefore, good food preservation techniques must prevent microbial spoilage of food without affecting its quality and nutrition. Earlier the quality control was done at the end products stage. But this has now given way to new concept like ISO 9000 , Hazard Analysis Critical Control Point (HACCP) etc. Quality control has changed in to quality assurance which starts rights from the point of catch, hygienic handling and storage, onboard the fishing vessel, handling, transportation, storage, preprocess handling, processing, packing and storage of the finished products to the end marketing. Spoilage of food products is due to chemical, enzymatic or microbial activities. One-fourth of the world's food supply and 30\% of landed fish are lost through microbial activity alone [4]. Fresh and clean foods are important to good nutrition. Spoilage organisms such as bacteria and moulds in food can both reduce the food's nutrient value and cause disease. Disease causing (or pathogenic) bacteria can contaminate food and water and leads to food poisoning. This spread of diseases such as typhoid, cholera and hepatitis. Microbial spoilage is by far the most common cause of spoilage and may manifest itself as visible growth (slime, colonies), as textural changes (degradation of polymers) or as off-odors and off-flavors. It has been estimated that $25 \%$ of all foods produced globally is lost post harvest or post slaughter due to microbial spoilage [5]. Food spoilage microorganisms are good in HACCP and do not cause illness. Excessive, prolonged growth of spoilage by microorganisms changes the odor, flavor, and texture of the food so much that it becomes unpalatable. The present study was aimed to find out the degree of bacterial and fungal contamination of the cooked curries of fish and shellfishes which stored in TFS cans.

\section{Materials and Methods}

The prepared curries of fish, shrimp, crab and mussel were stored in TFS cans at room temperature $\left(30 \pm 2^{\circ} \mathrm{C}\right)$ for a period of 18 months. During storage the cans were periodically checked in the intervals of $3^{\text {rd }}, 6^{\text {th }}$ and $12^{\text {th }}$ months especially the visual signs of internal and external rusting like appearance of can walls, adhesion of product to the can walls and internal rusting (Figure 1).

\section{Commercial sterility (IS: 2168-1971)}

About eight cans were selected at random from each batch processed to different $\mathrm{F}_{\mathrm{o}}$ values. Four cans from each batch were

*Corresponding author: N. Pushparajan, Faculty of Marine Sciences, Centre of Advanced Study in Marine Biology, Annamalai University, Parangipettai-608502, Tamil Nadu, India, Tel: 04144-243223; Fax: 04144-243553; E-mail natanapushpan@gmail.com

Received April 04, 2013; Accepted May 13, 2013; Published May 20, 2013

Citation: Pushparajan N, Varadharajan D, Soundarapandian P (2013) Microbia Studies of Prepared Curries Stored in Tin Free Steel Cans. J Food Process Technol 4: 238. doi:10.4172/2157-7110.1000238

Copyright: @ 2013 Pushparajan N, et al. This is an open-access article distributed under the terms of the Creative Commons Attribution License, which permits unrestricted use, distribution, and reproduction in any medium, provided the original author and source are credited. 
incubated at $55^{\circ} \mathrm{C}$ for 4 days and another four were incubated at $37^{\circ} \mathrm{C}$ for 14 days. The incubated cans were opened under aseptic conditions and the samples were transferred to sterile thioglycollate broth tubes. Then a layer of sterile liquid paraffin was applied in each tube so as to create anaerobic condition. The tubes were then incubated at $37^{\circ} \mathrm{C}$ for $48 \mathrm{hrs}$ and observed for any development of turbidity, which indicates survival of microorganisms. Tubes not showing any turbidity were incubated for further $48 \mathrm{hrs}$ at $37^{\circ} \mathrm{C}$ to ascertain the sterility. Besides the above microbiological quality were assessed from the fish, shrimp, crab and mussel curries by standard Plate count, Total Coliforms Count and Total Fungal count, according to APHA. Different types of media were used for the microbiological quality assessment, i.e., Nutrient agar (NA) and Potato Dextrose agar (PDA).

One gram of the tissue sample was weighed aseptically and blended with $1 \mathrm{ml}$ of sterile distilled water. From the blended mixture $1 \mathrm{ml}$ was transferred into $100 \mathrm{ml}$ of sterile distilled water and made upto $10^{-4}$ dilution (Figure 2). From the dilution each mixture, $0.1 \mathrm{ml}$ was poured onto Nutrient Agar as well as Potato dextrose agar. The nutrient agar plates were then incubated at $37^{\circ} \mathrm{C}$ and PDA plates were incubated at room temperature. After the incubation period, they were observed for the microbial colonies.

\section{Results and Discussion}

Enzymes are proteins which assist biological reactions, e.g. the conversion of certain organic substances into different ones. When fish

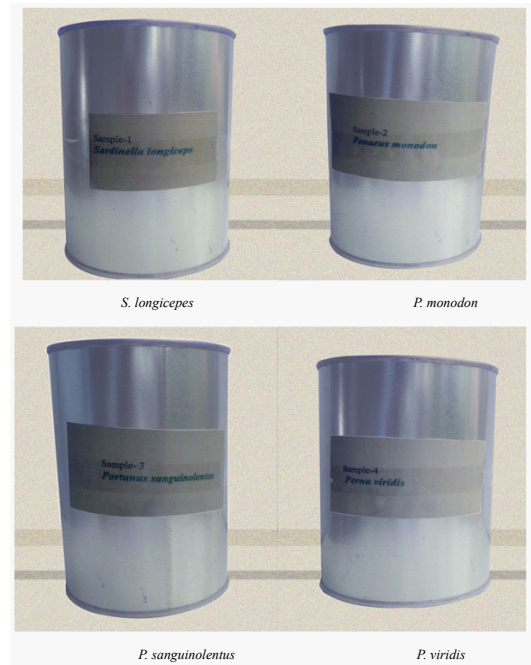

Figure 1: Prepared curries of fish, shrimp, crab and mussel for storage examination.

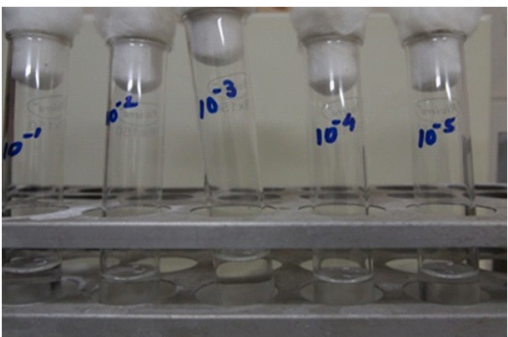

Figure 2: Total plate count or animals are killed, the enzymes inside them are still intact. Those enzymes start breaking down components into smaller parts. This affects smell, taste and texture. Several hours after death "Rigor mortis" occurs (a stiffening of the flesh). After that the flesh gets softer again due to enzymatic reactions (autolysis). Heat treatment e.g. pasteurization can inactivate enzymes. Shortly after capture, chemical and biological changes take place in dead fish due to enzymatic breakdown of major fish molecules [6]. Hansen et al. [7] stated that autolytic enzymes reduced textural quality during early stages of deterioration but did not produce the characteristic spoilage off-odors and off-flavors. This indicates that autolytic degradation can limit shelf-life and product quality even with relatively low levels of spoilage organisms. Most of the impact is on textural quality along with the production of hypoxanthine and formaldehyde. The digestive enzymes cause extensive autolysis which results in meat softening, rupture of the belly wall and drain out of the blood water which contains both protein and oil [8]. A number of proteolytic enzymes are found in muscle and viscera of the fish after catch. These enzymes contribute to post mortem degradation in fish muscle and fish products during storage and processing. There is a sensorial or product associated alteration that can be contributed by proteolytic enzymes [9]. During improper storage of whole fish, proteolysis is responsible for degradation of proteins and is followed by a process of solublization [10]. On the other hand, peptides and free amino acids can be produced as a result of autolysis of fish muscle proteins, which lead towards the spoilage of fish meat as an outcome of microbial growth and production of biogenic amines [11]. Belly bursting is caused by leakage of proteolytic enzymes from pyloric caeca and intestine to the ventral muscle. The proteases have optimal $\mathrm{pH}$ in the alkaline to neutral range. Martinez et al. [12] reported that the rate of degradation by proteolytic enzymes was reduced when the fish was kept at $0^{\circ} \mathrm{C}$ and a $\mathrm{pH}$ of 5 .

With fatty fish or meat, chemical reactions can take place between the fat and oxygen in the air (oxidation reactions). By exposing these products for a longer time to air, e.g. during drying and smoking, the product acquires a rancid smell and taste. It is therefore better to use less fatty kinds or pieces of fish or meat for smoking and drying microorganisms and most of the spoilage microorganisms are destroyed. This makes the cooked food far more vulnerable to a few pathogens on hands or from cutting board cross-contamination of cooked food. With correct temperatures and no competition from spoilage microorganisms, the contaminating pathogens grow well. Temperature abuse also allows spores to outgrow into vegetative cells. Lipid oxidation is a major cause of deterioration and spoilage for the pelagic fish species such as mackerel and herring with high oil/fat content stored fat in their flesh [11]. Lipid oxidation involves a three stage free radical mechanism: initiation, propagation and termination [12]. Initiation involves the formation of lipid free radicals through catalysts such as heat, metal ions and irradiation. These free radicals which react with oxygen to form peroxyl radicals. During propagation, the peroxyl radicals reacting with other lipid molecules to form hydroperoxides and a new free radical $[11,13]$. Termination occurs when a buildup of these free radicals interact to form nonradical products. Oxidation typically involves the reaction of oxygen with the double bonds of fatty acids. Therefore, fish lipids which consist of polyunsaturated fatty acids are highly susceptible to oxidation. Molecular oxygen needs to be activated in order to allow oxidation to occur. Transition metals are primary activators of molecular oxygen [13]. In fish, lipid oxidation can occur enzymatically or non-enzymatically. The enzymatic hydrolysis of fats by lipases is termed lipolysis (fat deterioration). During this process, lipases split 
the glycerides forming free fatty acids which are responsible for: (a) common off flavor, frequently referred to as rancidity and (b) reducing the oil quality $[8,14]$. The lipolytic enzymes could either be endogenous of the food product (such as milk) or derived from psychrotrophic microorganisms [14]. The enzymes involved are the lipases present in the skin, blood and tissue. The main enzymes in fish lipid hydrolysis are triacyl lipase, phospholipase A2 and phospholipase B $[15,16]$. Nonenzymatic oxidation is caused by hematin compounds (hemoglobin, myoglobin and cytochrome) catalysis producing hydroperoxides [11]. The fatty acids formed during hydrolysis of fish lipids interact with sarcoplasmic and myofibrillar proteins causing denaturation $[17,18]$. Undeland et al. [19] reported that lipid oxidation can occur in fish muscle due to the highly pro-oxidative Hemoglobin $(\mathrm{Hb})$, specifically if it is deoxygenated and/or oxidized. They found that the addition of acids, which lower the $\mathrm{pH}$, can accelerate lipid oxidation through deoxygenated $\mathrm{Hb}$.

Fresh fish spoilage can be very rapid after it is caught. The spoilage process (Rigor mortis) will start within $12 \mathrm{hrs}$ of their catch in the high ambient temperatures of the tropics [20]. Rigor mortis is the process through which fish loses its flexibility due to stiffening of fish mussels after few hour of its death [21]. Most fish species degrade as a result of digestive enzymes and lipases, microbial spoilage from surface bacteria and oxidation [22]. During fish spoilage, there is a breakdown of various components and the formation of new compounds. These new compounds are responsible for the changes in odor, flavor and texture of the fish meat. This represents a major concern of the freshness of saleable products and the breakdown of proteins and lipids. Higher energy demanding freeze-storage preservation can be altered by synthetic or natural preservatives for control of lipid oxidation and microbial growth in fish during storage [23]. Combination of these preservatives and refrigeration diminishes the process of spoilage [24]. Compositional changes during fish spoilage result in lipid oxidation and protein degradation as well as the loss of other valuable molecules. In order to develop optimum preservation techniques for these value added products in active forms, understanding of the mechanism responsible for their degradation is essential.

When food spoilage is caused by the growth of yeasts and moulds it is self-evident: a furry growth covers the food and it becomes soft and often smells bad. Bacterial contamination is more dangerous because very often the food does not look bad: even though severely infected, it may appear quite normal. The presence of highly dangerous toxins and bacterial spores is often not detected until after an outbreak of food
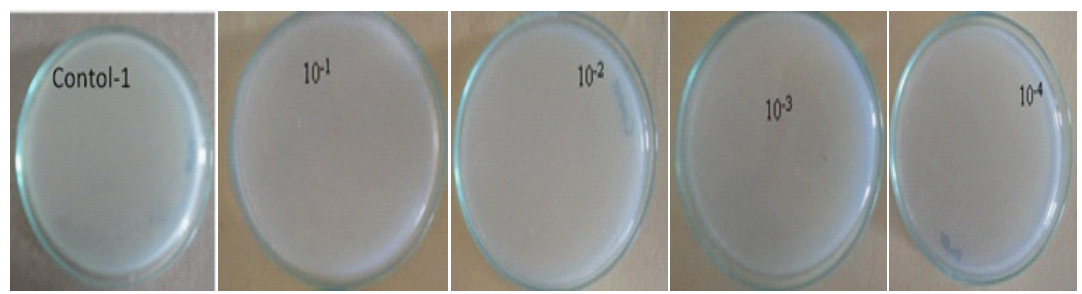

S.longiceps
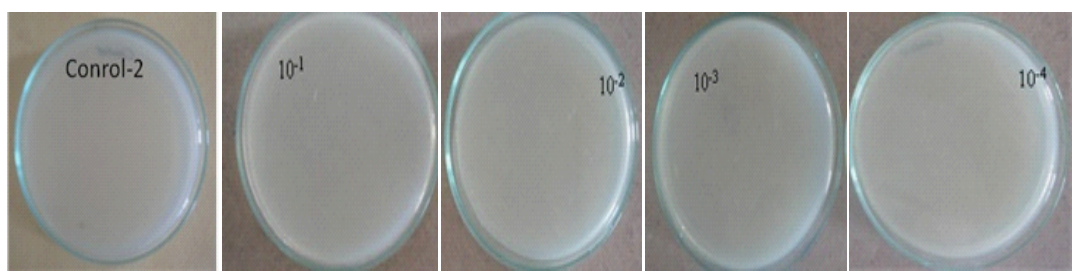

P.monodon
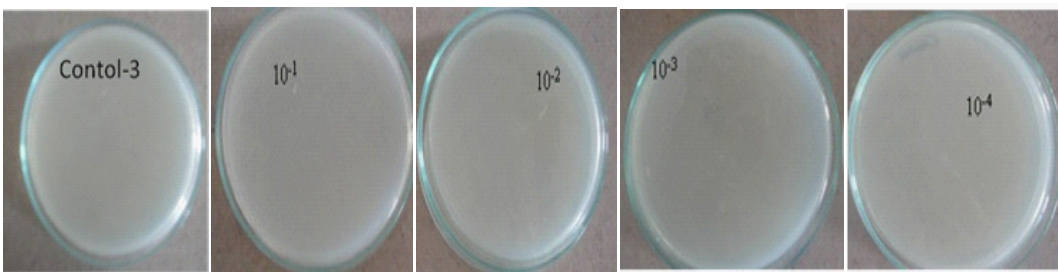

P.sanguinolentus
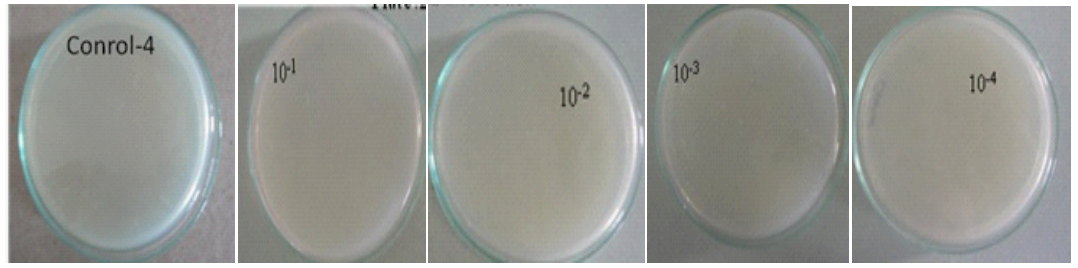

P.viridis

Figure 3: Bacterial count after $3^{\text {rd }}$ month storage of fish, shrimp, crab and mussel curries cultured in nutrient agar. 


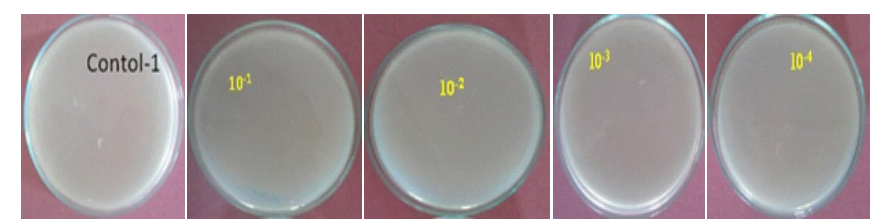

S.longiceps

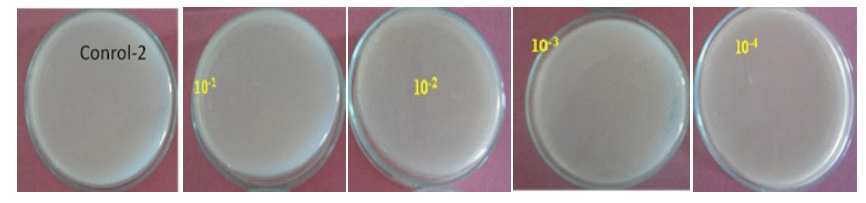

P.monodon

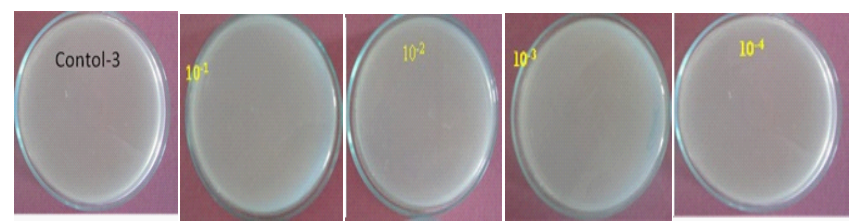

P.sanguinolentus

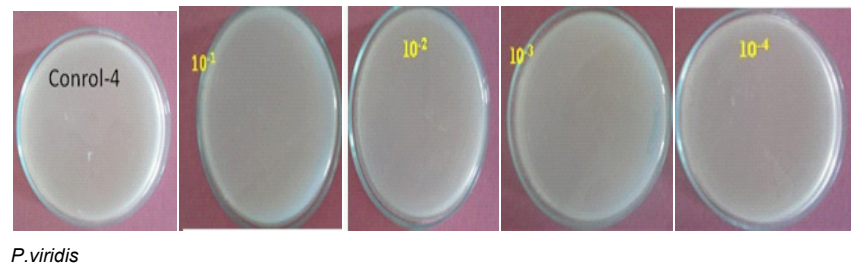

Figure 4: Bacterial count after $6^{\text {th }}$ month storage of fish, shrimp, crab and mussel curries cultured in nutrient agar.

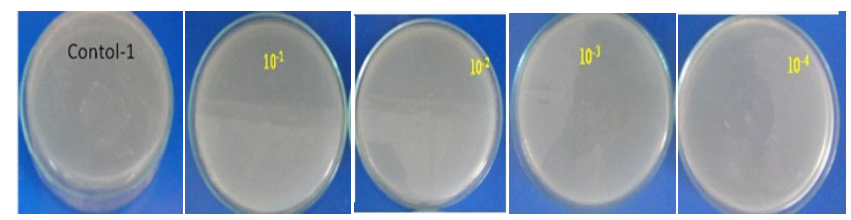

S.longiceps

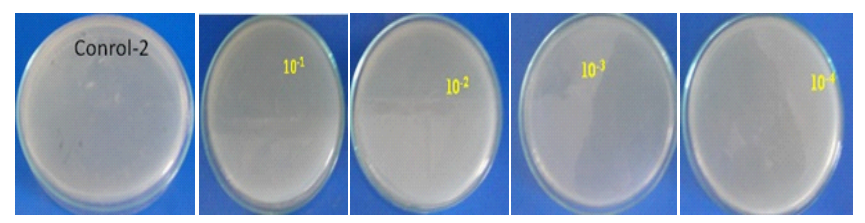

P.monodon

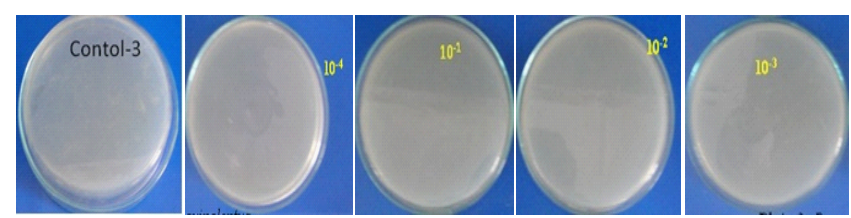

P.sanguinolentus

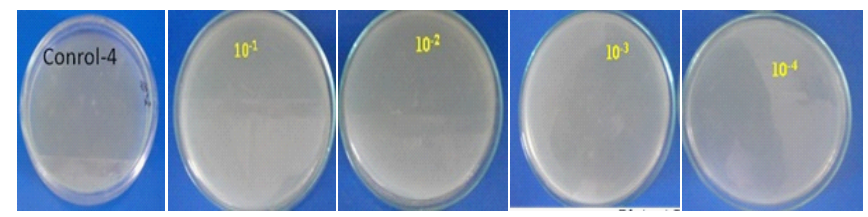

P.viridis

Figure 5: Bacterial count after $12^{\text {th }}$ month storage of fish, shrimp, crab and mussel curries cultured in nutrient agar. 


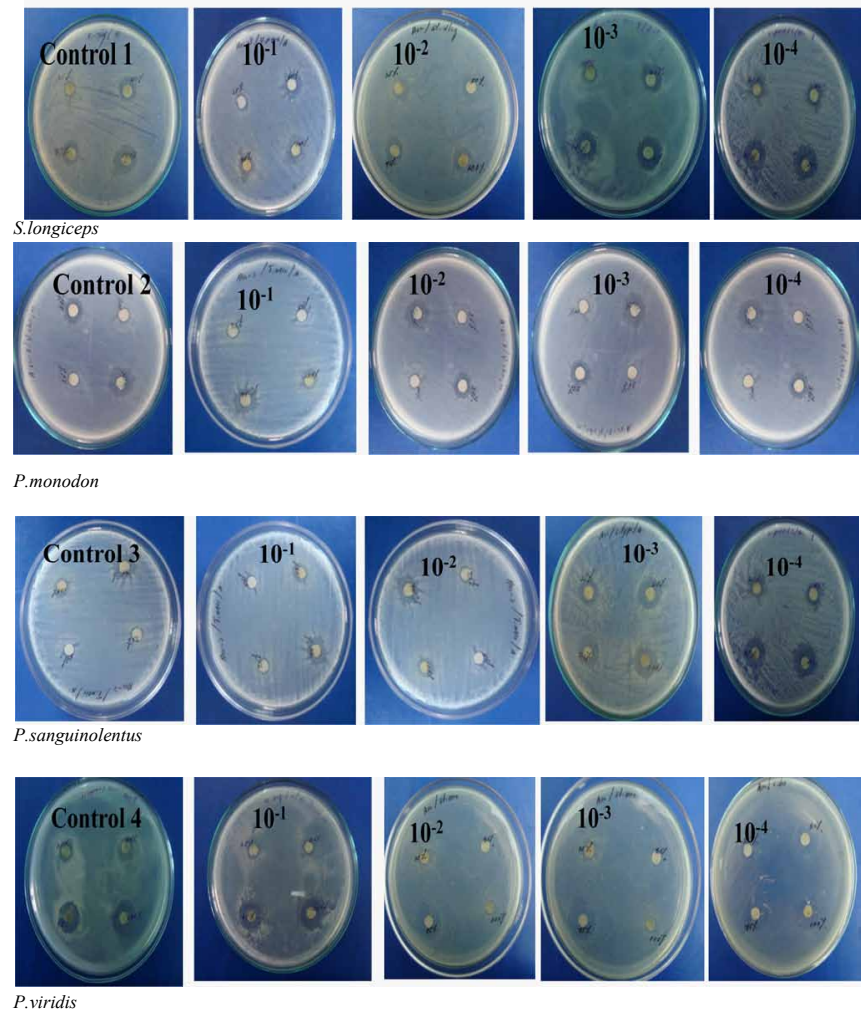

Figure 6: Fungal count after $3^{\text {rd }}$ month storage of fish, shrimp, crab and mussel curries cultured in potato dextrose agar.
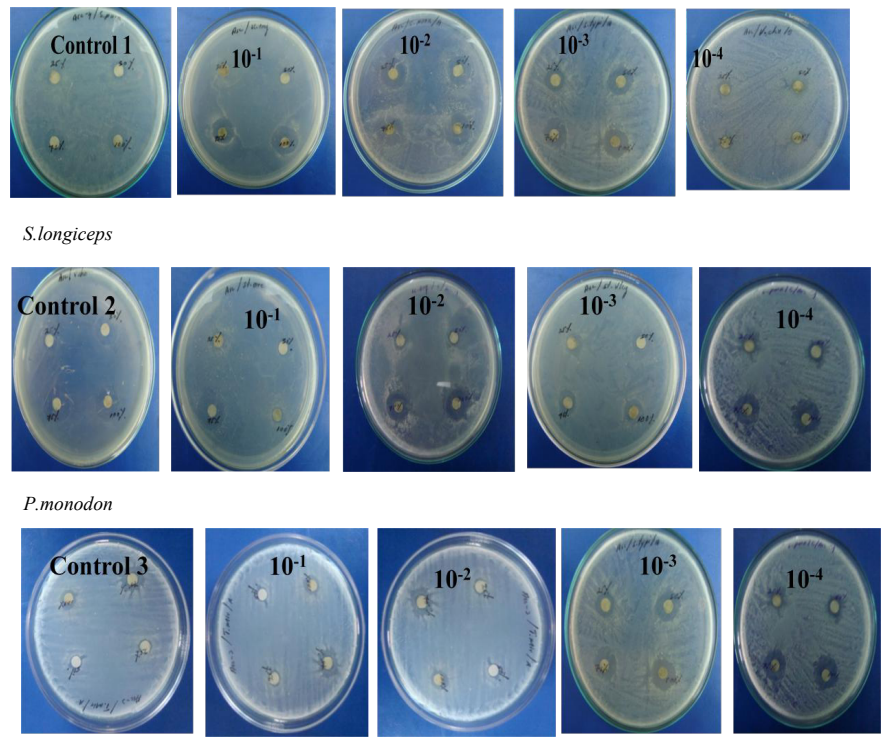

P.sanguinolentus
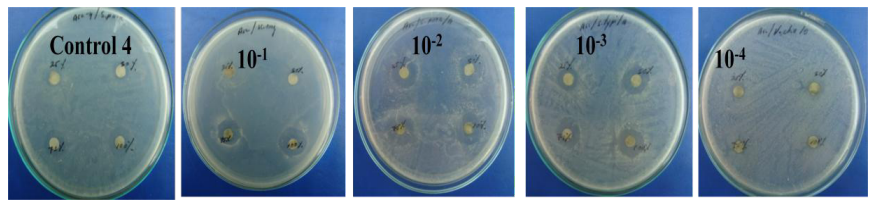

P.viridis

Figure 7: Fungal count after $6^{\text {th }}$ month storage of fish, shrimp, crab and mussel curries cultured in potato dextrose agar. 

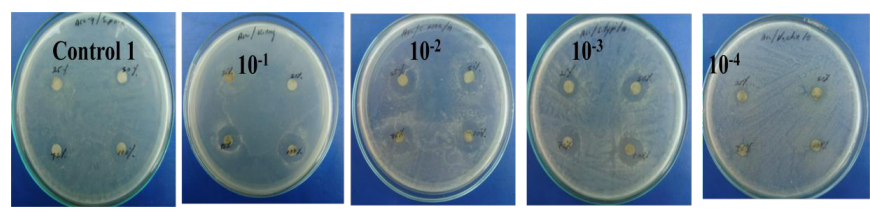

S.longiceps
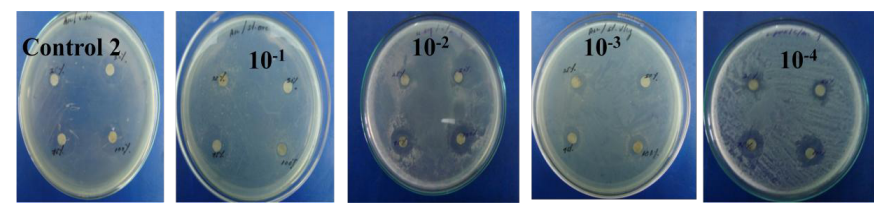

P.monodon
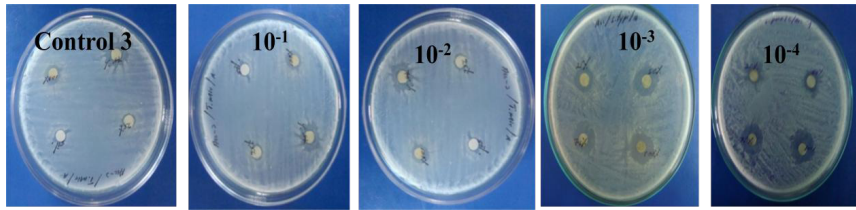

P.sanguinolentus
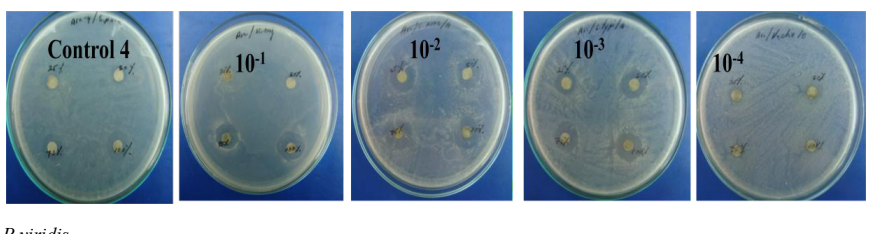

P.viridis

Figure 8: Fungal count after $12^{\text {th }}$ month storage of fish, shrimp, crab and mussel curries cultured in potato dextrose agar.

poisoning, when laboratory examination and experiments uncover the infecting agent. Landed fish harbours on its body large number of microorganisms. The most commonly used method for testing the raw material bacterial quality is the total viable count. Total aerobic bacterial counts had been used by many investigators to follow the deterioration of fish flesh and shellfish flesh [25-27]. The microbiological quality as indicated by the total plate count of the raw materials was within the range of $10^{2}-10^{4} \mathrm{~g}-1$ (Figure 3-8). Similar results for various species of landed fish and prawn were reported by many workers [28-30]. In the present study microorganisms are totally absent for the entire samples during the storage period of eighteen months.

Spoilage of food products can be due to chemical, enzymatic or microbial activities. Chemical deterioration and microbial spoilage are responsible for loss of $25 \%$ of gross primary agricultural and fishery products every year [31]. One-fourth of the world's food supply [14] and $30 \%$ of landed fish [32] are lost through microbial activity alone. Around 4-5 million tons of trawled and shrimp fish are lost every year due to enzymatic and microbial spoilage because of improper onsite storage. Fish tissues are contaminated more readily than meat because they are of a looser consistency and are easily penetrated. Canned foods are sterilized before being placed on the grocery shelf, but if the sterilization has been unsuccessful, contamination or food spoilage may occur. Swollen cans usually contain gas produced by members of the genus Clostridium. Sour spoilage without gas is commonly due to members of the genus Bacillus. This type of spoilage is called flat-sour spoilage. Lactobacilli are responsible for acid spoilage when they break down the carbohydrates in foods and produce detectable amounts of acid. The flat sour spoilage is caused mainly dominated by thermophilic spore-farming bacteria such as B. thermoacidurans, B. coaqulans, and
B. stearother mophilus. Terixeria et al. [33] proposed a short review of recent development towards achieving computer-based intelligent online control system for assuring safety quality and process efficiency of thermally processed canned food. Pettibone et al. [34] has also reported that heat resistance of fish pathogens obtained from fish and fishery products. Most outbreak of food poisoning associated with fish derived from the consumption of raw or insufficiently heat treated fish which will contaminate with bacteria from water environment. Vibrio, C. botulinum or terrestrial sources or fish products recontaminated during heat processing [35-37].

In Netherlands there are an estimated 700,000 cases of illness and 80 deaths per year [38]. Also other industrialized countries report a continuing burden of foodborne illness [39-41]. Food borne outbreaks appear to be on the rise again in some industrialized countries, with a shift from traditional problems with foods from animal origin to fresh foods such as produce [42], shellfish [43] and dry products and ingredients (e.g. peanuts) [44]. Furthermore, new threats continue to be identified. The attention for viruses is more recent, but no less relevant. New risks are being encountered because of changing characteristics of the relevant micro-organisms, changing production methodologies, changes in the environment and the ecology, and an increase of the global trade of foodstuffs. In addition, demands on food $\backslash$ safety increase steadily. The attention by Food Regulatory Agencies and Food Processing Industry, proper handling, pre treatment and preservation techniques can improve the quality of fish and fishery products and increase their shelf life. Storage of food at high temperature causes a loss of nutritional value. The chemical composition of the food and the metabolic activates of the organisms growing in the food determine the compounds which can be used as indicators, because of the extreme 
perish ability of some products, occasionally decomposed foods get into market channels [45]. The microorganisms are totally absent in the present study for short and longer time storage ( 3 to 18 months) of fish and shellfish curries stored in TFS cans. Apart from that there is no internal and external rusting, texture during the storage period. So it is conform that TFS cans are suitable can to store the fish and shellfish products as evidence by no microbial growth and also not affecting the nutritional quality of the stored food.

\section{References}

1. Birgisdottir BE, Kiely M, Martinez JA, Thorsdottir I (2008) Validity of a food frequency questionnaire to assess intake of seafood in adults in three European countries. Food Control 19: 648-653.

2. Delgado CL, Wada N, Rosegrant MW, Meijer S, Ahmed M (2003) Fish to 2020: Supply and Demand in Changing Global Markets. International Food Policy Research Institute, Washington, DC.

3. Wang F, Zhang J, Mu W, Fu Z, Zhang X (2009) Consumers perception toward quality and safety of fishery products, Beijing, China. Food Control 20: 918-922.

4. Ghaly AE, Dave D, Budge S, Brooks MS (2010) Fish Spoilage Mechanisms and Preservation Techniques: Review. American J Appl Sci 7: 859-877.

5. Anonymous (1985) An Evaluation of the Role of Microbiological Criteria for Foods and Food Ingredients. Subcommittee on Microbiological Criteria: Committee on Food Protection; Food and Nutrition Board; National Research Council, National Academy Press, Washington, DC.

6. FAO (2005) Post-harvest changes in fish. In: FAO Fisheries and Aquaculture Department, Food and Agriculture Organization, Rome, Italy.

7. Hansen TL, Gill T, Rontved SD, Huss HH (1996) Importance of autolysis and microbiological activity on quality of cold-smoked salmon. Food Res Int 29 $181-188$

8. FAO (1986) Fisheries Technical Papers-T142. The production of fish meal and oil. Fisheries Industries Division, Food and Agriculture Organization of the United Nations, Rome, Italy.

9. Engvang K, Nielsen HH (2001) Proteolysis in Salmon (Salmo salar) During Cold Storage: Effects of Storage Time and Smoking Process. J Food Biochem 25: 379-395

10. Lin TM, Park JW (1996) Protein Solubility in Pacific Whiting Affected by Proteolysis During Storage. J Food Sci 61: 536-539.

11. Fraser O, Sumar S (1998) Compositional changes and spoilage in fish. Nutr Food Sci 98: 275-279.

12. Martinez A, Gildberg A (1988) Autolytic degradation of belly tissue in anchovy (Engraulis encrasicholus). Int J Food Sci Technol 23: 185-194.

13. Hultin HO (1994) Oxidation of lipids in seafoods. In: Seafoods: Chemistry, Processing Technology and Quality, Shahidi, F. and J.R. Botta (Eds.), 1st Edn., Blackie Academic and Professional, London, UK, pp 49-74.

14. Huis in 't Veld JH (1996) Microbial and biochemical spoilage of foods: an overview. Int J Food Microbiol 33: 1-18.

15. Yorkowski M, Brockerhoff H (1965) Lysolecthinase of Cod Muscle. J Fish Res 22: 643-652.

16. Audley MA, Shetty KJ, Kinsella JE (1978) Isolation and Properties of Phospholipase A from Pollock Muscle. J Food Sci 43: 1771-1775.

17. King FJ, Anderson ML, Steinberg MA (1962) Reaction of Cod Actomyosin with Linoleic and Linolenic Acids. J Food Sci 27: 363-366.

18. Anderson ML, Ravesi EM (1969) Reactions of Free Fatty Acids with Protein in Cod Muscle Frozen and Stored at $-26^{\circ} \mathrm{C}$ after Aging in Ice. J Fish Res 26 : 2727-2736.

19. Undeland I, Hall G, Wendin K, Gangby I, Rutgersson A (2005) Preventing lipid oxidation during recovery of functional proteins from herring (Clupea harengus) fillets by an acid solubilization process. J Agric Food Chem 53: 5625-5634.

20. Berkel BM, Boogaard BV, Heijnen C (2004) Preservation of fish and meat. Agromisa Foundation, Wageningen, The Netherlands.

21. Adebowale BA, Dongo LN, Jayeola CO, Orisajo SB (2008) Comparative
Quality Assessment of Fish (Clarias gariepinus) Smoked with Cocoa Pod Husk and Three other Different Smoking Materials. J Food Technol 6: 5-8.

22. AMEC (2003) Management of wastes from Atlantic seafood processing operations. AMEC Earth and Environmental Limited, Dartmouth, Nova Scotia, Canada.

23. Mahmoud BSM, Yamazaki K, Miyashita K, Shin II, Suzuki T (2006) A new technology of fish preservation by combined treatment with electrolysed $\mathrm{NaCl}$ solutions and essential oil compounds. Food Chem 99: 656-662.

24. Bagamboula CF, Uyttendaele M, Debevere J (2004) Inhibitory effect of thyme and basil essential oils, carvacrol, thymol, estragol, linalool and p-cymene towards Shigella sonnei and S. flexneri. Food Microbiol 21: 33-42.

25. Griffiths FP, Stansby ME (1934) Significance of the Bacterial Count and Chemical Tests in Determining the Relative Freshness of Haddock. Trans Am Fisheries Soc 64: 401-407.

26. Fitzgerald GA, Conway WS (1937) Sanitation and Quality Control in the Fishery Industries. Am J Public Health Nations Health 27: 1094-1101.

27. Novak AF, Fieger EA, Bailey ME (1956) Rapid procedures for approximation of bacterial counts in shrimp and oysters. Food Technol 10: 66-67.

28. Laxmanan PT, Mathan C, Varma PRG, Iyer TSG (1984) Assessment of quality of fish landed at the Cochin fisheries harbour. Fish Technol 21: 98-105.

29. Surendran PK, Iyer KM, Gopakumar K (1985) Effectiveness of EDTA dips on the shelf life of oil sardine (Sardinella longicapes), mackerel (Rastrellige kanagurta) and shrimp (Metapenaeus dobzoni) in iced storage. Fish Technol 22: 29-34

30. Karunasagar I, Rosalind G, Karunasagar I, Malathi GR (1992) Virulence of seafood associated strains of non 01 Vibrio cholerae. In: Huss H., Jakobsen $M$ \& Liston J. (Eds). Quality Assurance in the Fish Industry. Elsevier Sci Pub Amst p. 211-216.

31. Baird-Parker TC (2000) The Production of Microbiologically Safe and Stable Foods. In: The Microbiological Safety and Quality of Food, Lund, B.M. and T.C Baird-Parker (Eds.). Aspen Publishers Inc., Gaithersburg, MD. USA pp 3-18.

32. Amos B (2007) Analysis of Quality Deterioration at Critical Steps/Points in Fish Handling in Uganda and Iceland and Suggestions for Improvement. United Nations University, Uganda

33. Terixeria AA, Tucker GS (1997) On-line retort control in thermal sterilization of canned foods. Food Control 8: 13-20.

34. Pettibone GW, Mear JP, Sampsell BM (1996) Incidence of antibiotic and meta resistance and plasmid carriage in Aeromonas isolated from brown bullhead (Ictalurus nebulosus). Lett Appl Microbiol 23: 234-240.

35. Khatib R, Naber M, Shellum N, Ashton L, Knowles K, et al. (1994) A common source outbreak of gastroenteritis in a teaching hospital. Infect Control Hosp Epidemiol 15: 534-535

36. Kobayashi T, Kimura B, Fujii T (2000) Strictly anaerobic halophiles isolated from canned Swedish fermented herrings (Surströmming). Int J Food Microbio 54: 81-89.

37. Novotny L, Dvorska L, Lorencova A, Beran V, Pavlik I (2004) Fish: A potential source of bacterial pathogens for human beings. Vet Med Czech 49: 343-358.

38. Havelaar AH, Van Duynhoven YTHP, Van Pelt W (2008) Microbiological pathogens in food. Scope of the problem. How often does ziekteals result of microbiological pathogens in food? In: Health Future Study, National Public Health Compass. Bilthoven, RIVM.

39. Adak GK, Meakins SM, Yip H, Lopman BA, O'Brien SJ (2005) Disease risks from foods, England and Wales, 1996-2000. Emerg Infect Dis 11: 365-372.

40. The Community Summary Report on Trends and Sources of Zoonoses Zoonotic Agents, Antimicrobial resistance and Foodborne outbreaks in the European Union in 2006. The EFSA J 130: 1-352.

41. Jones TF, Scallan E, Angulo FJ (2007) FoodNet: overview of a decade of achievement. Foodborne Pathog Dis 4: 60-66

42. Centers for Disease Control and Prevention (CDC) (2008) Outbreak of Salmonella serotype Saintpaul infections associated with multiple raw produce items--United States, 2008. MMWR Morb Mortal Wkly Rep 57: 929-934.

43. Pontrelli G, Boccia D, DI Renzi M, Massari M, Giugliano F, et al. (2008) Epidemiological and virological characterization of a large community-wide outbreak of hepatitis A in southern Italy. Epidemiol Infect 136: 1027-1034. 
Citation: Pushparajan N, Varadharajan D, Soundarapandian P (2013) Microbial Studies of Prepared Curries Stored in Tin Free Steel Cans. J Food Process Technol 4: 238. doi:10.4172/2157-7110.1000238

Page 8 of 8

44. Centers for Disease Control and Prevention (CDC) (2009) Multistate outbreak of Salmonella infections associated with peanut butter and peanut buttercontaining products--United States, 2008-2009. MMWR Morb Mortal Wkly Rep 58: 85-90.
45. Sayed SA (2002) Studies on baby foods. M.Sc. Thesis, Food science and technology, Department of Faculty of Agriculture University. Egypt. 